症例

胸腔鏡による肺部分切除を施行した肺硬化性血管腫の 1 例

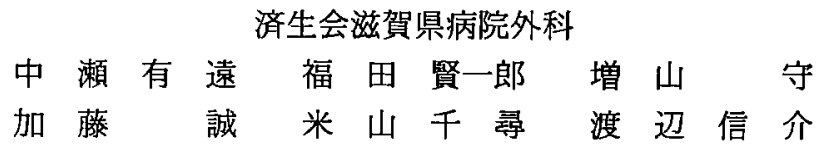

症例は68歳女性。平成10年 9 月に両側変形性滕関節症に対し, 全身麻醉での手術を予 定していたが，術前の胸部単純レントゲンで右下肺野に約 $1.5 \mathrm{~cm}$ の円形陰影を指摘さ れ, 精査, 治療目的に入院した。院時, 身体所見, 血液生化学検查に特に異常を認め なかった. 胸部 CT にて, 辺緑明瞭で内部均一な腫瘤陰影が右 S 8 に認められたが, 胸膜 の陥入やリンパ節の腫脹は認められなかった，気管支鏡検查の範囲では異常を認めなか った。しかし，悪性腫瘍を否定し得ず，診断的治療目的に胸腔鏡による肺部分切除を施 行した。病理検査にて肺硬化性血管腫と診断された。

肺硬化性血管腫は肺末梢に好発する比較的稀な良性腫瘍である. その術前診断は困難 であり, 術中迅速標本でも診断し得ないことがあるとされている。このような症例に, 胸腔鏡手術は低侵襲であり，確定診断をか木た治療として推奨されると考えられた。

索引用語：肺硬化性血管腫，胸腔鏡手術

はじめに

肺硬化性血管腫は比較的稀な肺の良性腫湟である が，その術前診断は困難であり，術中迅速標本でも診 断し得ないことがある. 今回われわれは，胸腔鏡によ る肺部分切除を施行し，確定診断した肺硬化性血管腫 を経験したので若干の文献的考察を加え報告する。

\section{症例}

症例：68歳，女性.

既往歴，家族歴：特記すべきものなし。

現病歴: 平成 10 年 9 月に両側変形成滕関節症のた め, 全身麻酔での手術を予定していたが, 術前の胸部 単純レントゲン写真で右下葉に異常陰影を指摘され, 精查, 治療のため入院となる。

来院時現症：身長 $145 \mathrm{~cm}$, 体重 $64 \mathrm{~kg}$. 呼吸音に異常 を認めなかった。

入院時検查成績：血液生化学検査に特に異常を認め なかった。

胸部単純レントゲン：右下肺野に径 $1.5 \mathrm{~cm}$ の淡い 円形陰影を認めた（図 1 )。

胸部 CT 検查：辺緑明暸で内部均一な腫瘤陰影が右 S8に認められたが，胸膜の陥入やリンパ節の腫脹は認

1999年 5 月 21日受付 1999 年11月10日採用
められなかった（図 2).

気管支鏡検査：検查の範囲では異常を認めなかっ た.

以上より，悪性を否定し得ない肺腫瘤であり，診断 的治療目的に胸腔鏡による肺部分切除を施行した.

手術所見：第 6 肋間鎖骨中線上でトロッカーを㨂 入, 胸腔内を検索したが胸水, 胸膜癒着, 肺門リンパ 節の腫大を認めなかった。腫瘾は右 S 8 に存在し, 突出 していたが臟側胸膜に浸潤は認めなかった（図 3 )。 GIA により肺部分切除を行った。 なお，凍結標本によ る術中迅速組織診断は行っていない.

摘出標本肉眼所見：腫瘤は径 $1 \mathrm{~cm}$ ほどで弾性軟で あり, 周囲との境界は明瞭であった。割面は充実性で 硬い黄白色の部分と暗赤色の柔らかい部分が混在して いた。

病理組織学的検査：肺胞構築あるいは血管内皮の増 生を思わせるような乳頭状構造がみられ，肺胞上皮と 思われる細胞が被覆していた。一部には石灰化も観察 され，肺硬化性血管腫と診断された（図 4)。

免疫組織学的検査：上皮細胞の指標である抗 cytokeratin 抗体を用いた免疫染色で乳頭状部分の上皮細 胞だけでなく硬化部分の紡錘型細胞にも陽性像が観察 された(図 5 )。また，II 型肺胞上皮細胞の指標である 


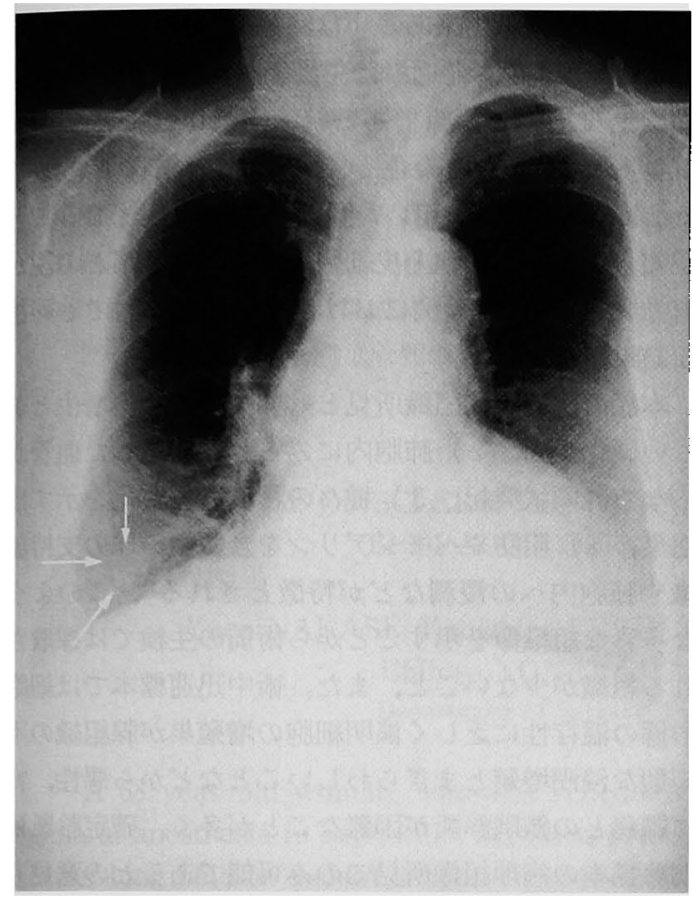

図 1 胸部単純レントゲン：右下肺野に径 $1.5 \mathrm{~cm}$ の淡い 円形陰影を認めた。

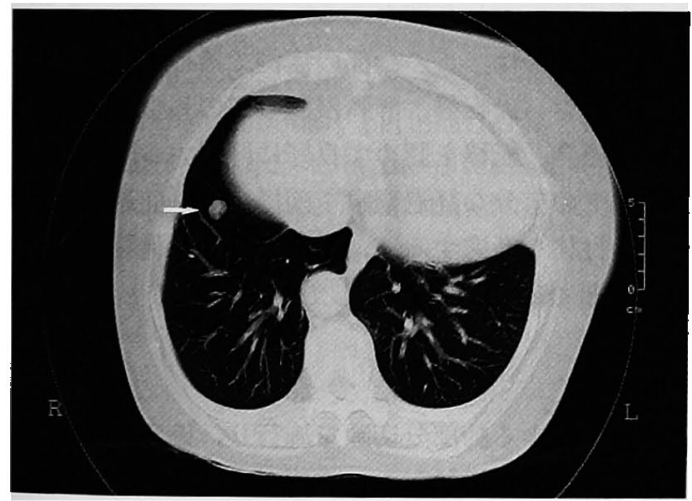

图 2 胸部 CT 検查：辺緑明膫で内部均一な腫瘤陰影が 右 S 8 に記められたが, 胸膜の陥入やリンパ節の腫脹は 認められなかった。

抗 surfactannt apoprotein 抗体を用いた免疫染色で は乳頭部分を構築する細胞の胞体内部, 核内封入体が 顆粒状に陽性であった（図 6 ）。

術後経過：良好に経過し，術後 9 日目に退院した。 2 力月後に整形外科において全身麻酔手術を特に合併 症なく施行している。現在, 外来にて経過観察中であ る.

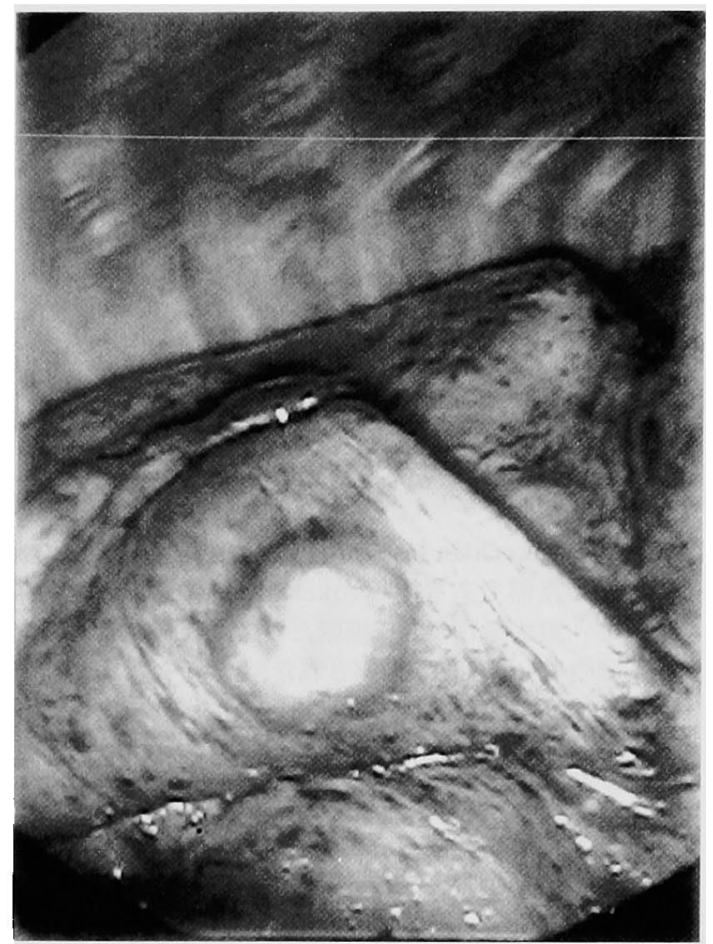

图 3 手術所見：腫瘤は右 S 8 に存在し，乫出していた が葴側胸膜に浸潤は認めなかった。

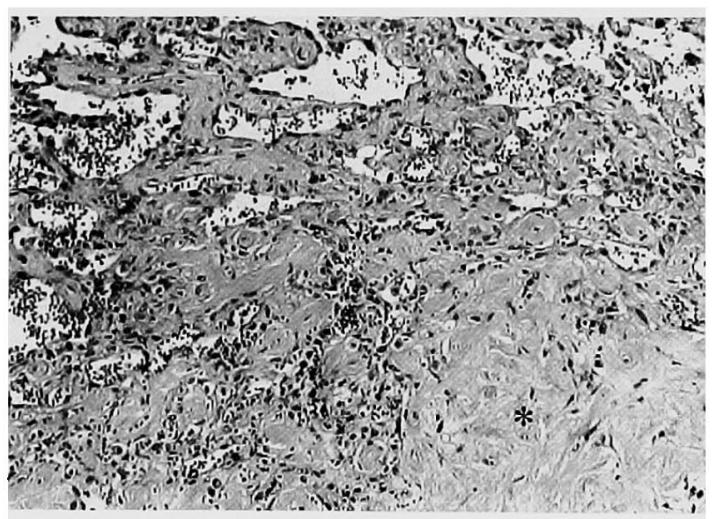

図 4 HE 染色 $(\times 20)$ : 肺胞構築あるいは血管上皮の增 生を思わせるような乳頭状構造がみられ，肺胞上皮と思 われる紐胞が被覆していた(写真の左上部分)。一部には 石灰化も観察され 写真の右下 $*$ の部分)，肺硬化性血管 腫と診断された。

\section{考 察}

肺硬化性血管腫は1956年 Liebowにより初めて報告 された疾患である゙が，画像診断の進歩により最近そ の報告は増加して扔り,検索し得た限りでは約 300 例を 


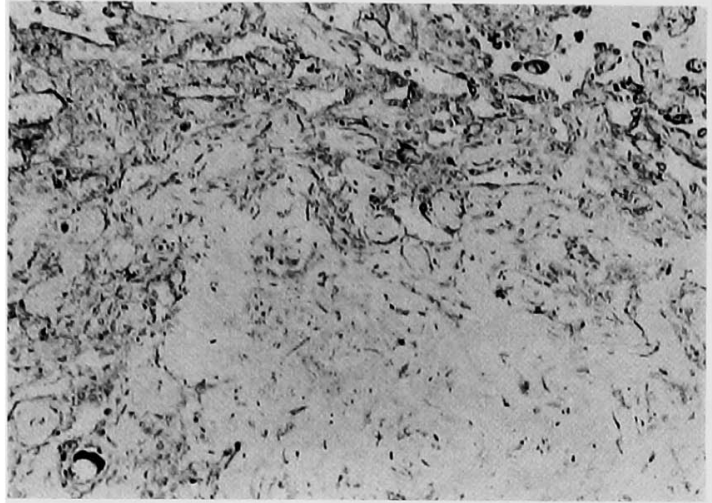

図 5 抗 cytokeratin 抗体を用いた免疫染色 $(\times 20)$ : 上 皮細胞の指標である抗 cytokeratin 抗体を用いた免疫 染色で乳頭状部分の上皮細胞だけでなく硬化部分の紡 鍾型細胞にも陽性像が観察された。

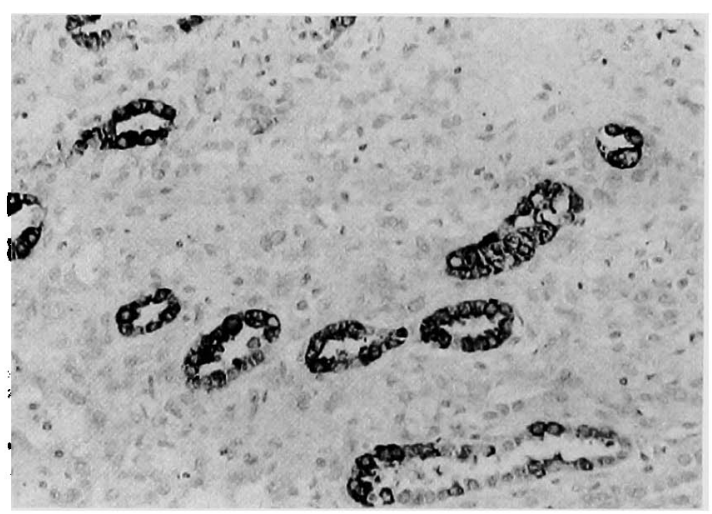

図 6 抗 surfactant apoprotein 抗体を用いた免疫染色 $(\times 200)$ : II 型肺胞上皮細胞の指標である抗 surfactant protein 抗体を用いた免疫染色で乳頭部分を構 築する細胞の胞体内部，核内封入体が顆粒状に陽性であ った.

\section{数える.}

本症は30～50歳代の女性に好発し，特に下葉，肺末 梢に多いとされる ${ }^{2)}$. 胸部単純レントダン写真で肺野 の孤立性陰影を示すことが多く，末梢型肺腺癌，転移 性肺癌，過誤腫などとの鑑別を要する．ほとんどは無 症状であり，検診などで偶然発見されることが多いが, 稀に血疾，咳，胸痛を呈することがある゙，

胸部単純レントゲン写真や CT, MRI による鑑別診 断は難しく, 気管支動脈造影, 経気管支的生検, 経皮 的生検などで診断がつくこともあるが，一般的に術前 診断は困難であるとされる ${ }^{4) 5}$.

発生母地としては血管内皮由来, 中皮細胞由来, II
型肺胞上皮細胞由来あるいは間葉系細胞由来などが指 摘されてきた . 最近では免疫組織学的検討から II 型 肺胞上皮細胞の指標である抗 surfactant apoprotein 抗体を用いた免疫染色と上皮細胞の指標である抗 cytokeratin 抗体を用いた兔疫染色で陽性となること が報告されII 型肺胞上皮細胞由来の良性腫場との説が 有力である ${ }^{6}$. 自験例における免疫学的検討でも同様 な結果が得られた。

本症の病理学的組織所見として 1) 血管の增生と著 しい硬化傾向，2）肺胞内にみられる増生した血管氻 らなる乳頭状突起， 3 ）種々の程度の器質化を示す出 血巣，4）脂肪やへモジデリンを含む組織球の支持組 織や肺胞内への浸潤などが特徵とされる゙。このよう な多彩な組織像を示すことから術前の生検では採取さ れる組織が少ないこと，また，術中迅速標本では細胞 形態の温存性に乏しく淡明細胞の増殖巣が腺組織の不 規則な浸潤増殖とまぎらわしいことなどから悪性，特 に腺癌との鑑別診断が困難なことが多く，確定診断は 切除標本の病理組織所見でのみ可能であるとの意見も ある”。

治療としては開胸による肺部分切除, 肺葉切除が主 に行われてきた。また, 術中迅速標本で腺癌と䛦断さ れ，術式を拡大した例もある8

予後としては，ごく一部の症例で播種性再発，局所 再発，リンパ節転移，静脈浸潤などの報告があるが， 多くは再発，転移を認めず良好に経過する゙2。

外来での充分な経過観察を前提とし, 前述のような 本症の性格を考虑すると，低侵襲である胸靕鏡手術が 確定診断をかねた治療として推奖されると考えられ た.

\section{結 語}

胸腔鏡による肺部分切除を施行し，確定診断した肺 硬化性血管腫を経験した。本症が小病変として発見さ れた場合，低侵襲である胸腔鏡手術は確定診断をかね た治療として推奨されると考えられた。

稀を終えるにあたり病理組織所見に関してご指導いただ いた当院病理部九嶋亮治先生に深謝いたします.

\section{文 献}

1) Liebow AA, Hubbell DS: Sclerosing hemangioma (histiocytoma, xanthoma) of the lung. Cancer 9: 53-75, 1956

2）中谷行雄，小川伸郎，木村 均他：肺硬化性血管 腫の病理：Liebow から40年の進展. 病理と臨 $14: 172-180,1996$ 
3）木村寛伸，草島義徳，小西一郎他：肺硬化性血管 腫の 1 例と本邦196例の文献的検討. 日臨外医会誌 $49: 1403-1408,1988$

4) 早坂宗治, 本田孝行, 蜂谷 勤他 : 気管支鏡下穿 刺吸引細胞診にて診断した肺硬化性血管腫の 1

例. 気管支学 $15: 439-443,1993$

5）川島 修, 吉田一郎, 大谷嘉己他：気管支動脈造 影で誩断した肺硬化性血管腫の 1 例. 肺癌 34 ： 1065-1068, 1994
6）小川勝成, 尾田三世, 嶋本文雄 他：肺硬化性血管 嗹 2 例の細胞状態と免疫細胞化学的検討. 日臨細 胞会広島会報 $14: 35-38,1993$

7）望月 衛, 吉田京子, 萩原 昇他：いわゆる肺硬 化性血管腱の 3 例一術中迅速捺印細胞診と迅速組 織診併用の有用性一.磐城共立病医報 $17: 120$ 125, 1996

8）谷村葉子, 松崎安孝, 弥政晋輔他：肺硬化性血管 腫の1例. 日臨外会誌 $59: 2779-2782,1998$

\title{
A CASE OF SCLEROSING HEMANGIOMA OF THE LUNG TREATED BY THORACOSCOPIC PARTIAL PNEUMONECTOMY
}

\author{
Yuen NAKASE, Kenichiro FUKUDA, Mamoru MASUYAMA, Makoto KATO, \\ Chihiro YONEYAMA and Shinsuke WATANABE \\ Department of Surgery, Saiseikai Shiga Prefectural Hospital
}

A 68-year-old woman, who was scheduled to undergo operation for bilateral gonarthritis under general anesthesia in September 1998,was detected having an about $1.5 \mathrm{~cm}$ circular shadow in the right lower lung field on a chest simple $\mathrm{x}$-ray film taken preoperatively. She was admitted to the hospital for close examination and treatment, when no particular abnormalities in physical and blood biochemical data were observed. Chest CT scan revealed a demarcated tumor shadow with homogeneous center in the right S8, but no pleuralimpaction nor lymph nodes swelling was presented. Bronchoscopy revealed no anomalies. Since a possibility of malignant tumor could not be still ruled out, a thoracoscopy-aided partial pneumonectomy was performed for the purpose of examination and treatment. Pathological diagnosis was sclerosing hemangioma of the lung. Sclerosing hemangioma of the lung which commonly occurs in the pulmonary peripheries is a relatively rare benign tumor. We often have great difficulty in preoperative diagnosis of the disease, even by intraoperative frozen section diagnosis. For such cases, this thoracoscopic operation that is minimal invasive can be recommended to treat and also to make the definite diagnosis of the disease. 